
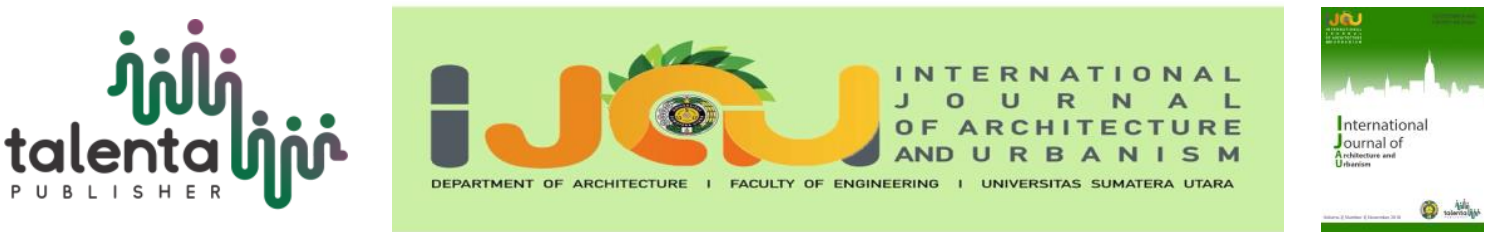

\title{
Organic Architecture as an Approach to Resort Hotels Design in the Simalem Park Tourism Area
}

\author{
B OY Marpaung ${ }^{1 *}$, Sakinah Hasibuan ${ }^{1}$ \\ ${ }^{1}$ Architecture Department, Faculty of Engineering, Universitas Sumatera Utara, Medan, Indonesia.
}

\begin{abstract}
Indonesian tourism is an industrial sector that is being elevated with the aim of increasing the country's foreign exchange income, and society in general, increase opportunities and employment, encouraging other industrial activities, introducing, empowering the use of natural beauty and Indonesian culture. Karo Regency is a tourist area that many visits, Karo District has nature potentials as a tourist attraction. In general, tourism has the potential for natural and historical tourism. Nature tourism includes lakes, parks, wildlife reserves or nature reserves, and cultural captures. Taman Simalem is one of the tourist areas in Karo Regency. Simalem Park tourist area is currently a tourist area that is a mainstay in Karo district with a large number of visitors who always increase each year. See so many tourism objects in Karo regency; it is necessary to build an accommodation service for tourists who want to vacation and enjoy the tourism objects. In buildings resort hotel accommodation services using organic themes then linking aspects of space that can adapt to the natural environment. The organic architectural theme approach is expected to facilitate the application of concepts that take shape from nature.
\end{abstract}

Keyword: Hotel, Resort, Organic.

\section{Introduction}

Indonesia is a country that has a tropical climate. This country is famous for its abundant natural wealth. In some areas there are also many natural forests and beautiful natural landscape, so that air and air are very safe and avoid pollution. Some lodging equipped with amenities natural that still fresh.

Taman Simalem tourist area is one of the most visits tourist attractions in North Sumatra Province. The location is on the hill of Merek, Sidikalang, near Lake Toba which provides various types of separate recreation with a cool atmosphere. Lodging provides in the form of resort hotels with natural scenery provide visual comfort for tourists.

*Corresponding author at: Department of Architecture, Faculty of Engineering, Universitas Sumatera Utara, Jalan Perpustakaan, Gedung J07, Medan, 20155, Indonesia

E-mail address: beny.marpaung@usu.ac.id 
Resort hotel accommodation has the main facilities of the bedroom, sitting room, bathroom, dining apartment, and terrace. There are also cottages and other supporting recreational facilities that are managed commercially and are supported by the natural surroundings that can meet the needs of visitors and foreign tourists. Organic architecture does not only refer to buildings. 'Connection to the natural environment, but how building design' is to think carefully as if it is a united organic.

The design of resort hotels in the tourist area of Simalem Karo park to support the area provides various functions and adds functions that do not yet exist as recreational places to enjoy the nature that is on Lake Toba [1].

Resort hotel project located are in the Taman Simalem tourist area located on Merk. This brand is one of the 17 cities located in Karo district. The Regency has an area of 2,127.25 km2 and has a population of around 500,000 people. This district located in the highlands of Karo, Barisan hill, North Sumatra. Located far as $77 \mathrm{~km}$ from the city of Medan, capital of North Sumatra province. The number of visitors to Simalem Park each year reaches 14,242 tourists (Figure 1).

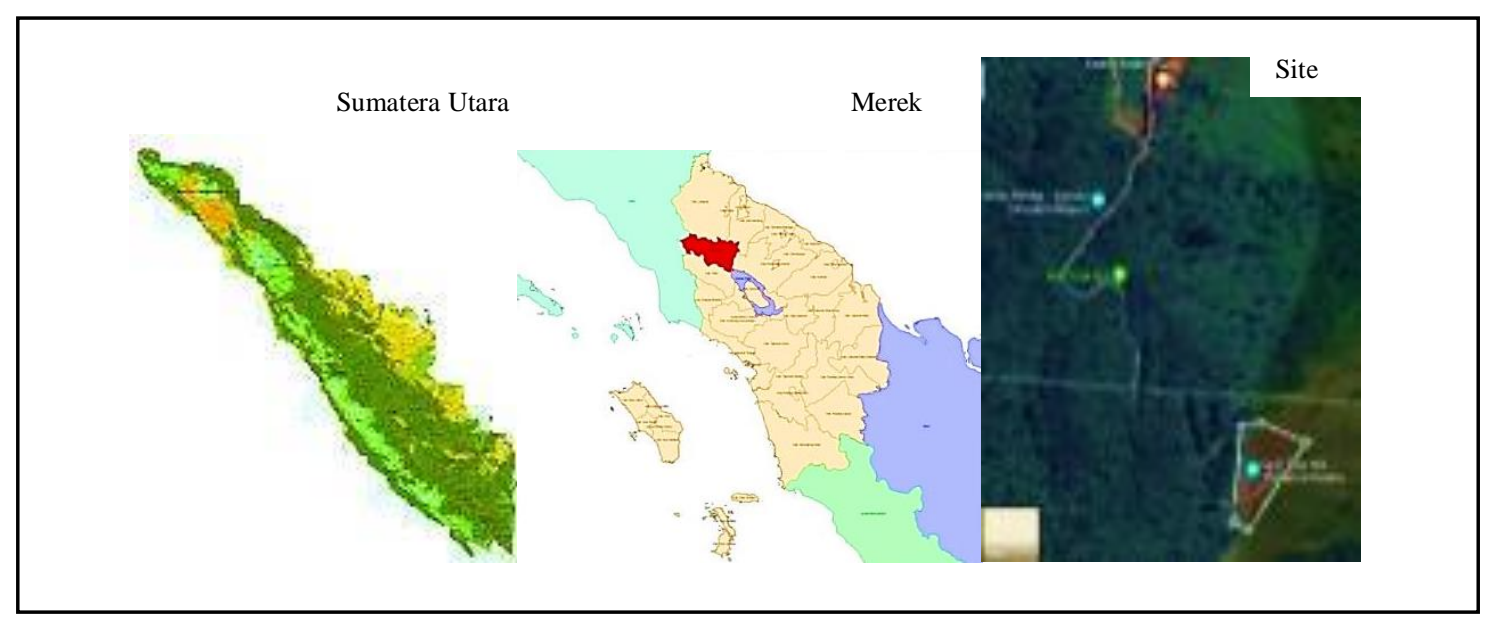

Figure 1. Location Map

\section{Literature Review}

For the design process, Organic Architecture is a theme as an approach in designing this resort hotel. A theme is an approach that is at the core of design. Organic Architecture selection is the desire to create conditions and atmosphere between physical buildings and unified outer spaces in sustainability designed by local environmental conditions. Organic architecture is more environmentally responsible, has a high level of harmony between structures, and the use of utility systems is very good so that it does not damage nature. Some organic architectures in buildings as the following supporting aspects (Table 1). 
Table1. Aspects of Organic Architecture Design

\begin{tabular}{llll}
\hline Organic Architecture & Aspect & Designing Instructions \\
& & \\
\hline $\begin{array}{l}\text { Shape building harmonious } \\
\text { with nature }\end{array}$ & $\begin{array}{l}\text { 1. A Building is formed } \\
\text { naturally from the site. The proportion of buildings }\end{array}$ & $\begin{array}{l}\text { and scale using fair. }\end{array}$
\end{tabular}

2. The Building is formed in 2. Eliminate the box's harmony with the proportion impression of the building and of the human body. adjust the area.

3. Build closer to nature. 3. The ground surface is parallel and not too high with horizontal elements.

\begin{tabular}{|c|c|c|}
\hline Organization dynamic space & $\begin{array}{l}\text { Space seemed to flow } \\
\text { continuously. }\end{array}$ & $\begin{array}{l}\text { The build-up follows the } \\
\text { circulation of the place in a } \\
\text { radial and linear pattern, for } \\
\text { the shape of the floor can be } \\
\text { adjusted to the pattern of the } \\
\text { site. }\end{array}$ \\
\hline Equation of space in space & $\begin{array}{l}\text { 1. The impression of the inner } \\
\text { and outside area. } \\
\text { 2. Exposure. }\end{array}$ & $\begin{array}{l}\text { Increases openings for natural } \\
\text { light into the building. }\end{array}$ \\
\hline $\begin{array}{l}\text { Materials, colors, ornaments } \\
\text { related to nature }\end{array}$ & $\begin{array}{l}\text { 1. Material from nature. } \\
\text { 2. Natural color }\end{array}$ & $\begin{array}{l}\text { Using natural materials in the } \\
\text { form of wood, bamboo, and } \\
\text { natural stone. For the use of } \\
\text { colors with natural } \\
\text { surroundings such as green, } \\
\text { brown, and other colors. }\end{array}$ \\
\hline
\end{tabular}

The Songjiang hotel is one of the five-star hotels; this hotel is inspired by natural water and permanent features around. This very innovative hotel has a capacity of 400 rooms and shared rooms with a capacity of 1,000 people. Some other facilities such as restaurants, cafes, public spaces are located below the water surface and sports facilities. The location associated with the Songiiang hotel location is as follows The build-up follows the circulation of the place in a 
radial and linear pattern, for the shape of the floor, can be adjusted to the pattern of the site. (Figure 2).

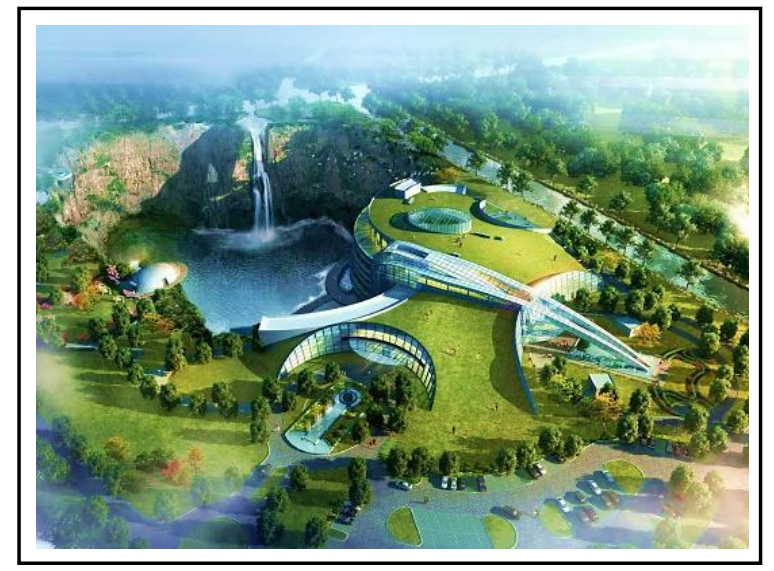

Figure 2. The Songjiang Hotel

(Source: Matthew Keegan, 2017)

Songjiang Hotels use a roof structure above the ground that is a green roof and has the power to withstand the extraction rate of geothermal energy. The water theme runs through slick and functional design slippery. This hotel has a giant aquarium in a restaurant about 100 meters long. This is the result of the design concept (Figure 3).

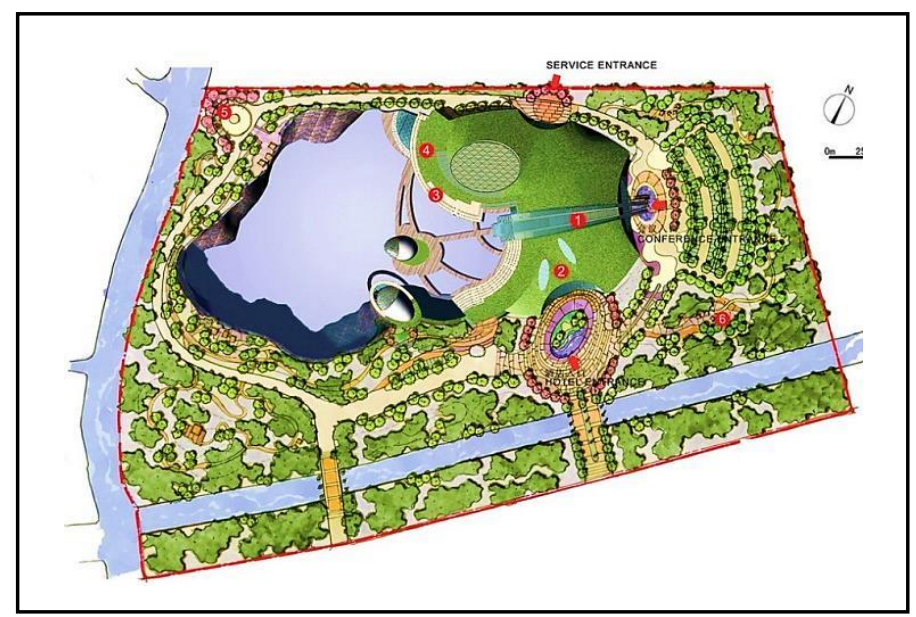

Figure 3.Master plan hotel Songjiang

(Source: Matthew Keegan, 2017)

Falling Water House is one example of organic architecture, a residence designed by Frank Lloyd Wright for the Kauffman family living in Pennsylvania. This house is just above the waterfall near the river which is quite steep with the sound of a waterfall. Regarding illustrations related to the design of the concept of water falling as follows [3].

Simple impressions are found at the main entrance which is dominated by wood material, followed by a building that is dominated by wood materials. There are river rocks with small 
waterfalls on the front. The fall of the water lies in the expanse of Oak and Maple forests. Regarding the illustrations related to the location of the water project falling as follows (Figure 4).

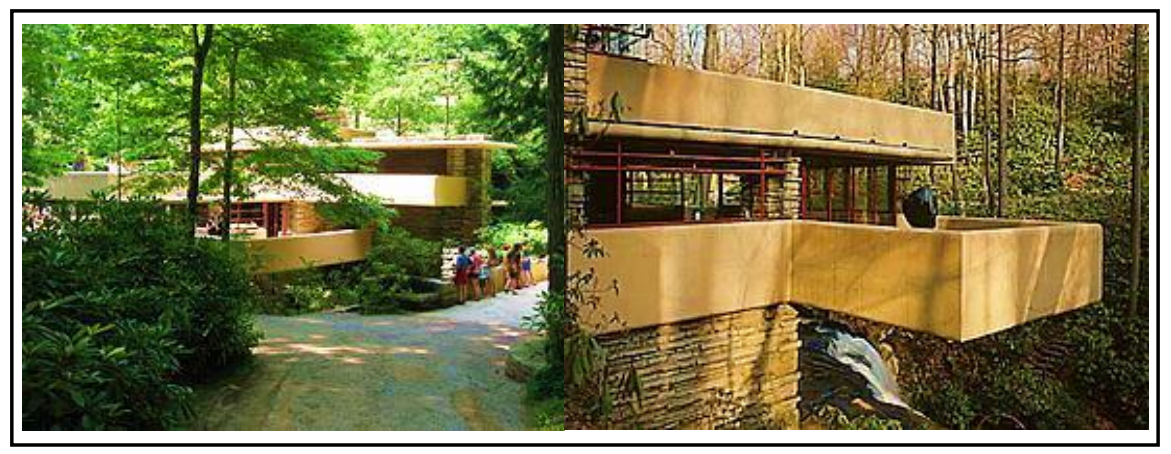

Figure 4.Falling Water House

(Source: Adelyn Perez, 2010)

Simple impressions are found at the main entrance which is dominated by wood material, followed by a building that is dominated by wood materials. There are river rocks with small waterfalls on the front. The fall of the water lies in the expanse of Oak and Maple forests. Regarding the illustrations related to the location of the water project falling as follows.

\section{Methodology}

In designing this project, the method used during site selection is a qualitative method with two aspects of the design theme approach and an environmental assessment approach. The research method is done to describe the activity or activities that occur there as objects; then the information is analyzed so that the problem can be solved. By comparing the site area to existing facilities and based on land regulations that have been established and follow the formation of existing environmental topologies. The technique for completing this design is required to collect secondary files in the form of literature, which relate to the facts that exist in nature around the location by observing them, gathering information directly so that they can know how to design, and determine external programs made.

An artificial environment that has a variety of uses to protect human beings and their activities and property from elements, and from the methods that have been done can create a safe and comfortable place that is harmless, emphasizing the status in accordance with the development and can make it a concern [4]. Architectural tasks are designed to respond to certain desires and problems. Which sometimes can only be seen in terms of function or may reflect certain conditions [5]. Good design can be seen from the understanding of architecture; it can be summarized that the environment is designed with the aim of preserving, protecting humans when interacting in the surrounding natural environment. 
The term "Organic" was first expressed and explained by biologists and anthropologists in the 1800s, namely Bichat, Linnaeus, Buffon, Lamark, Darwin, and Van Hombolt, It is an architecture based on the principles of development and growth. Has the most significant horizontal line of architecture, and can be seen the bond between nature and architecture. One of the works of architect Wright follows the basis of a new form that has a function of clarity of principle, which through architecture is the link between humans and the environment. Natural architecture is the basis for the development of basic development [6].

\section{Result and Discussion}

The design location is located in the southern part of the tourist area of Simalem park. This area has an area of 206 hectares owned by Taemin Sukardi in accordance with international standards equipped with views of Lake Toba. At the design location, it has been designated as a tourist area that will be designed as a hotel.

The basic design concept of applying organic architecture as a guideline will be used in a building in the form of a resort hotel. Organic architecture is one of the applications of harmony between its inhabitants and nature. By bringing harmony between the location of buildings, furniture, the environment that is one in composition, united and mutually personal. Therefore, in designing this resort hotel applying architectural concepts that can be used for the natural beauty that has been set in the tourist area of Simalem Park without destroying it.

The zoning division in the design location is divided into several parts. The main building area is in the northern part of the design location. The cottage area is the location that leads to Mount Sibayak. The recreation area is on the edge and the area closest to Lake Toba. Illustration with zoning design of the hotel resort design concept as follows (Figure 5).

\begin{tabular}{|l}
$\begin{array}{l}\text { Based on the potential of } \\
\text { the project location, the } \\
\text { main hotel area right in } \\
\text { this area faces a large } \\
\text { potential area. }\end{array}$ \\
$\begin{array}{l}\text { Supporting areas or } \\
\text { recreation areas are } \\
\text { designed in this section } \\
\text { to become the dance } \\
\text { power of the visiting } \\
\text { participants. }\end{array}$
\end{tabular}

Figure 5. Site Zoning Concept

In the design concept, the division is divided based on areas related to the level of importance and value of land. Lake Toba is the closest recreational area, located north of Lake Toba. While 
the main building is arranged in the middle section between the recreation area and the cottage area so that visitors in the main building can easily access the two areas, at the design location, buildings designed to follow the natural environment that already exists in the Taman Simalem tourism area. KDB size does not exceed the existing provisions, which is $40 \%$ of the design area. Regarding illustrations related to structuring the building as follows (Figure 6).

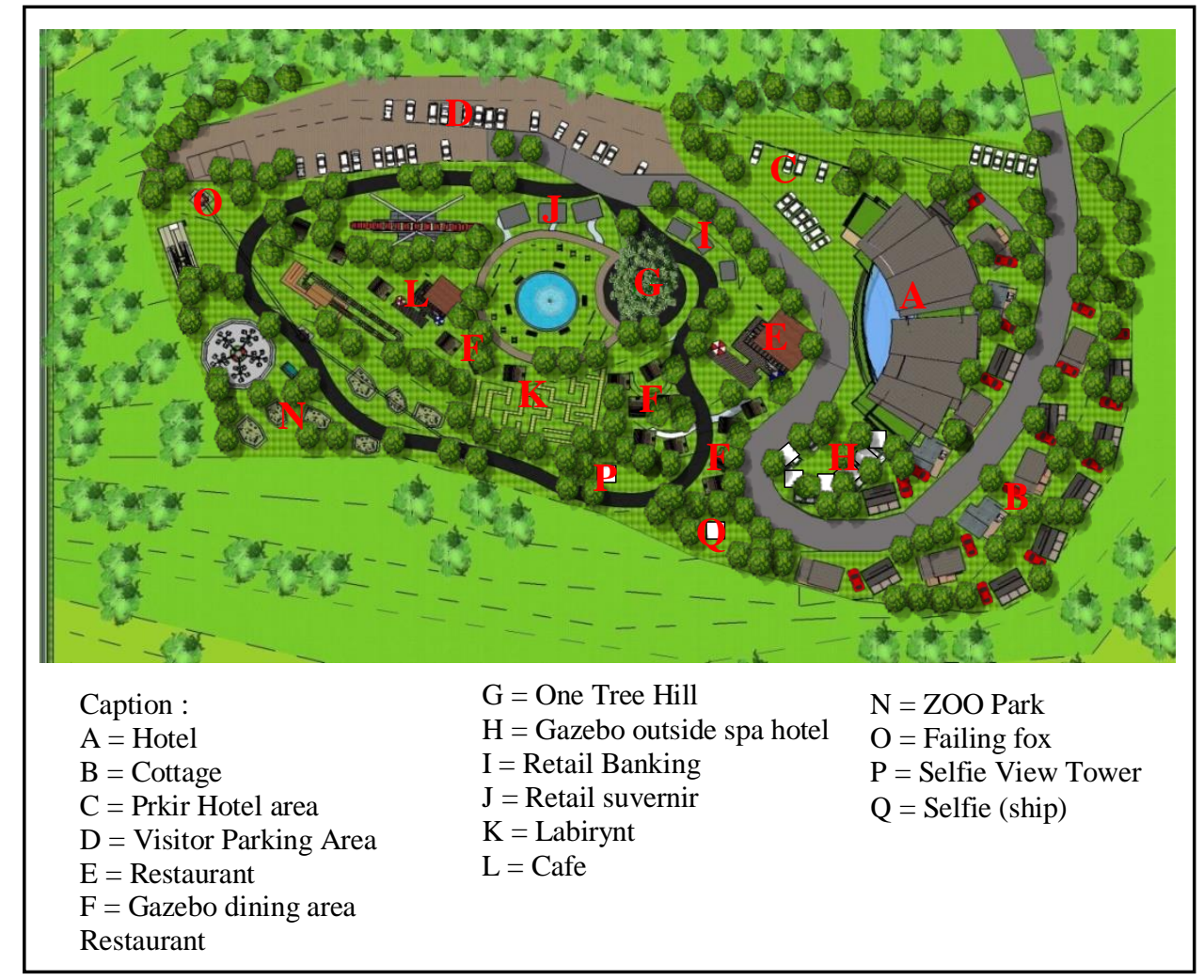

Figure 6. Concept of Site

The main building is a building that functions as a hotel with facilities that are the attraction of the hotel. The cottages are designed to follow the patterns and trees that are already on the site so that the size patterns of each cottage are different because adjusting the properties that exist with cottages make each type of cottage shape with a different form.

Vehicle circulation in the location of resort hotel design Simalem park tourism area is designed with two different paths, there are two directions, and one is in one direction. At the main entrance, the location is divided into one access point so that when accessing the facility must surround the facilities in the site design (Figure 7). 


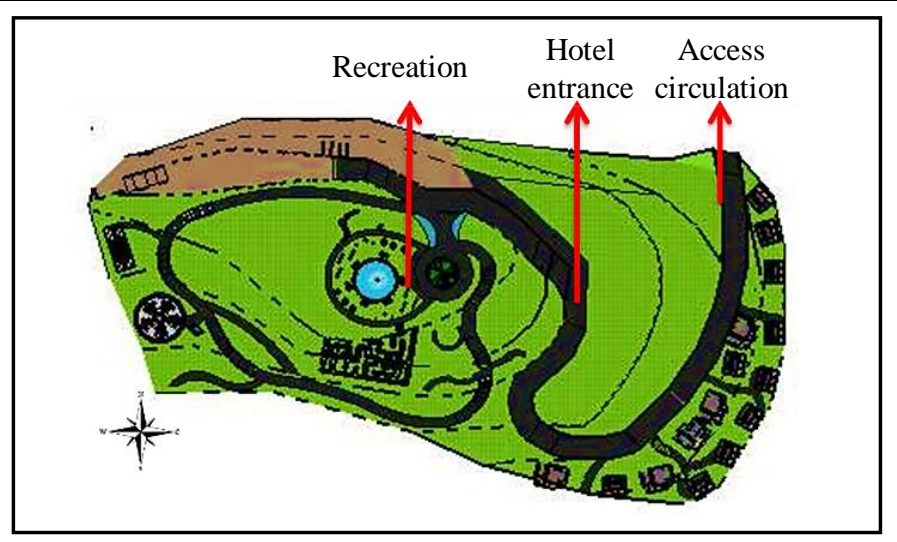

Figure 7. Circulation

Designing resort hotels in the Simalem Park area applies organic architecture. To strengthen this design idea, the concept is taken from the principle of organic architecture, as follows (Figure 8). Inspired by nature, Creating a space that is elastic, flexible, follows or flow Creating a space that is elastic, flexible, follows or flow, Repeat elements, Repeat elements, Expressing the concept of ideas strongly.

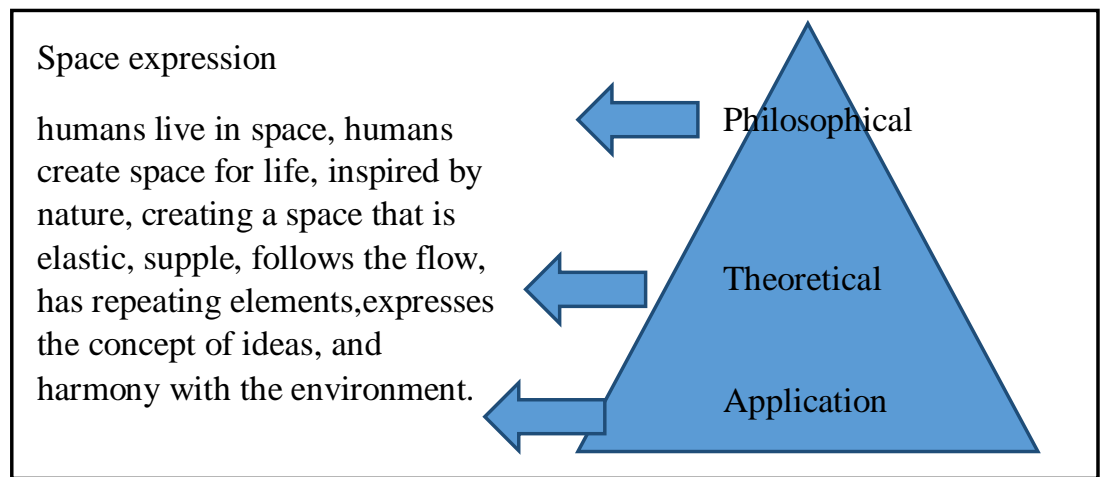

Figure 8. Architecture Design

The building takes the form of an organic theme, the natural form that is applied in this building follows the contour formation on the design site. The main building shape corresponds to a circle, and a square pattern is arranged by following the contour curve. Regarding the illustrations associated with the formation pattern can be seen as follows (Figure 9).

\begin{tabular}{|c|c|c|}
\hline $\begin{array}{l}\text { The shape of } \\
\text { the circle is } \\
\text { used to form the } \\
\text { curved side }\end{array}$ & $\begin{array}{l}\text { as a pointed side in the } \\
\text { elbows that are arranged to } \\
\text { repeat according to the } \\
\text { contour on the site }\end{array}$ & $\begin{array}{l}\text { The shape of the roof that uses a sloping roof } \\
\text { looks flexible and flexible according to site } \\
\text { conditions, and in harmony with nature. Form } \\
\text { the trimmed to conform to the structure }\end{array}$ \\
\hline
\end{tabular}

Figure 9. The concept of building 
The concept of a building takes the form of ornaments that are in the natural surroundings. The building also has a glass facade to show the natural beauty of the surrounding design area. Regarding the illustrations associated with the formation pattern can be seen as follows (Figure 10)

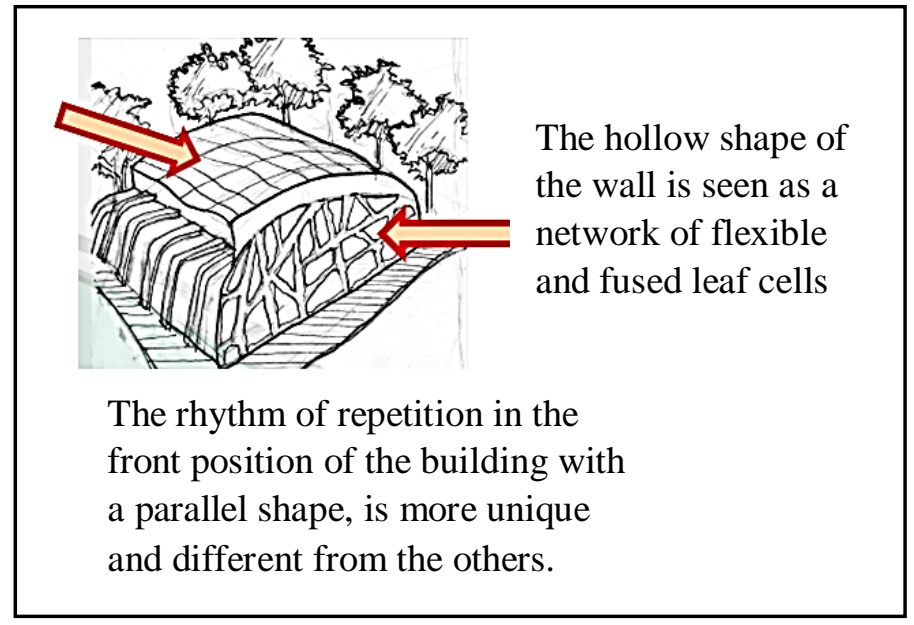

Figure 10. Face concept

Many tree branch facades that grow not far from the design location. Can be seen in the picture (Figure 11) This building is designed to be small on the bottom and width at the top.

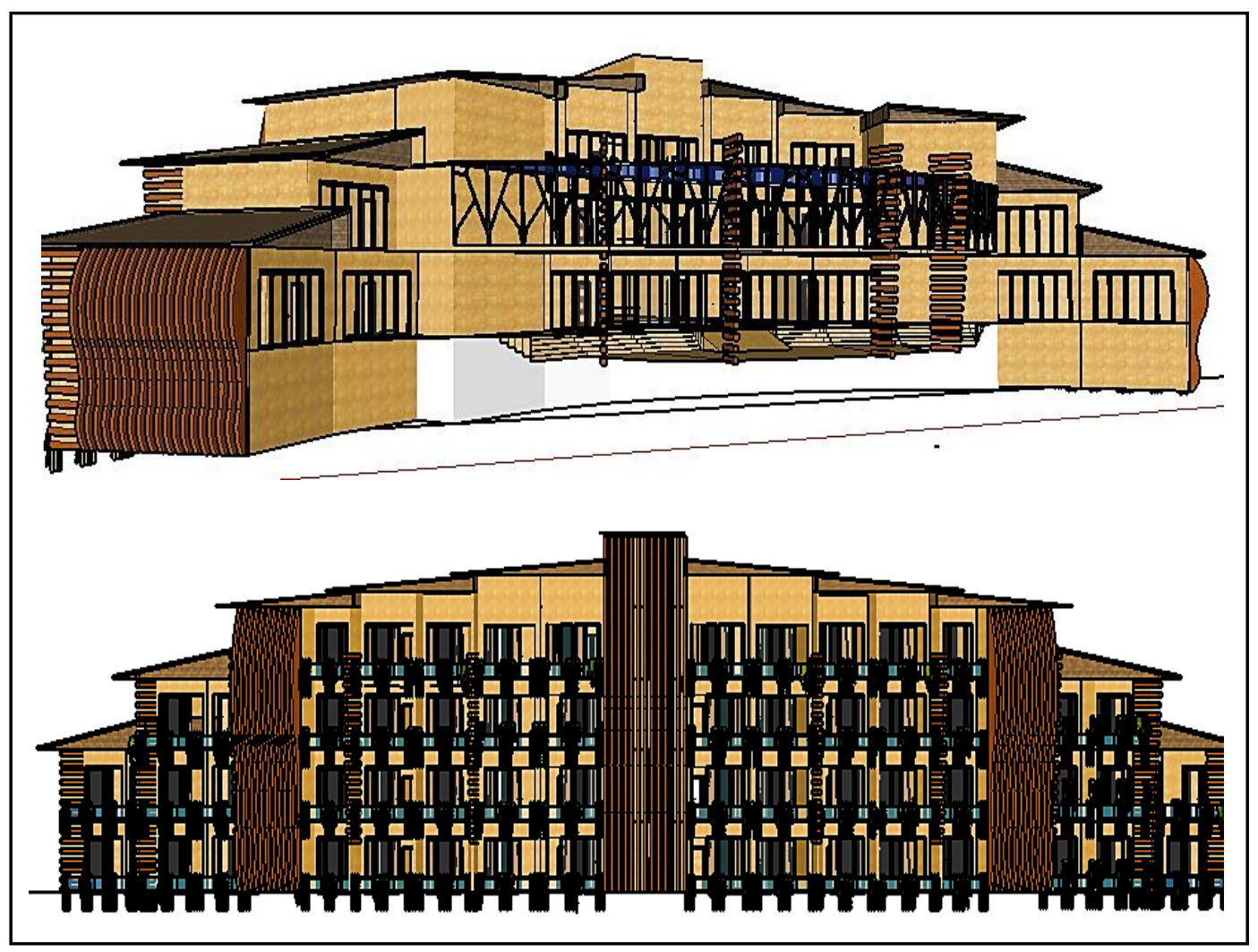

Figure 11. The facade of the hotel building 


\section{Conclusion}

The resort hotel project in the Simalem tourist area of Karo Regency with the Organic Architecture design concept, with a site area $=23,198,93 \mathrm{~m} 2$. Design building forms and site plans that use dynamic lines or do not seem rigid. For laying and construction orientations obtained from site analysis which is a land contour but has a good view of Lake Toba. Designing a resort hotel that serves as a residence that facilitates the needs of tourist visitors to Taman Simalem tourism area.

\section{Acknowledgment}

This researchers have prepared this article and was partly funded by the Department of Architecture Universitas Sumatera Utara as a contribution to the city government in planning and design to maintain existing local wisdom.

\section{REFERENCES}

[1] semedan.com, "peta lokasi simalem disumut," 2016/01/.

[2] M. Keegan, "Inside the World's First Underwater Quarry Hotel," the culture trip.com, p. 4, 2017.

[3] A. Perez, "AD Classics: Fallingwater House / Frank Lloyd Wright," archdaily.com, 2010.

[4] D. Sportt and L.Wilkes, "Understanding service oriented architecture," The Architecture jurnal, Vols. 1. no. 1. pp. 10-17, 2004.

[5] R. W. Berman, “Assessing Urban Design: Historical Ambience on The Waterfront," UK: Lexington books, 2006.

[6] A. F. Amir, and M. N. I. Ismail, and T. P. See, "Sustainable Tourist Environment: Perceptoin of International Women Travelers on Safety in Kuala Lumpur," Procedia - Social and Behavioral Science 168, pp.123-133, p. 6, 2015 